\title{
Antibiogram pattern of bacteria causing endometritis in cows
}

\author{
S. Udhayavel, S. Malmarugan, K Palanisamy ${ }^{1}$, J ohnson Rajeswar \\ Department of Veterinary Microbiology, \\ Veterinary College and Research Institute, Namakkal - 637002, Tamil Nadu, India \\ 1. Department of Obstetrics and Gynaecology, Veterinary College and Research Institute, Namakkal-637002 \\ Corresponding author: S. Malmarugan, email:micromals@rediffmail.com \\ Received: 10-06-2012, Accepted: 13-07-2012, Published online: 01-12-2012
}

\begin{abstract}
How to cite this article:
Udhayavel S, Malmarugan S, Palanisamy K and Rajeswar J (2013) Antibiogram pattern of bacteria causing endometritis in cows, Vet World 6(2): 100-102. doi: 10.5455/vetworld.2013.100-102
\end{abstract}

\begin{abstract}
Aim : To find out the organisms causing endometritis in cattle and to determine their in vitro sensitivity to various antibiotics

Materials and methods: Thirty uterine secretion samples, 9 from Holstein Friesian and 21 from Jersey cows were collected in and around Namakkal district of Tamil Nadu from clinical cases of endometritis. The bacteria isolated both aerobically and anaerobically from endometritis showed the characteristic colony, were gram stained and confirmed by standard biochemical tests. The invitro antibiotic sensitivity test with different antibiotic discs were carried out.
\end{abstract}

Results and Discussion: Out of 30 samples, 25 contained different strains of bacteria and 5 were found bacteriologically sterile. Different species of bacteria isolated from these samples were, Escherichia coli (36.66\%), Klebsiella spp (30\%), Proteus spp (13.33\%), Pseudomonas aeruginosa (6.66\%), Clostridium spp (3.33\%). The in vitro antibiotic sensitivity test indicated that the highest number of isolates (64\%) were sensitive to Ceftriaxone, followed by Gentamicin, Enrofloxacin and Chlortetracycline (32\%). Chloramphenicol showed sensitivity in minimum number (8\%) of isolates.

Conclusion : This study revealed that the bacteria E.coli and Klebisella spp are more commonly isolated in endometritis in cows and the drug Ceftriaxone is highly effective.

Key words: antibiotic sensitivity, bacteriology, cows, endometritis

\section{I ntroduction}

Metritis and endometritis are inflammation of the uterus. Metritis involves the endometrium, the underling glandular tissues and the muscular layer $[1,2]$. While, endometritis, is involves only the endometrium with the underlying glandular tissues [3], without any systemic signs [4]. Bacteriological contaminations of the uterus after parturition and metabolic changes in the transition period are important etiological factors for the occurrence of metritis and endometritis [5]. Endometritis is one of the most common reproductive disorder of buffaloes and cows. This problem not only affects milk yield but also decreases reproductive efficiency [6,7]. It is the main health problem in high producing cows $[8,9]$. Subclinical endometritis has been implicated as the most common cause of failure of conception in a high percentage of bovines in India [10]. Muneer et. al. [11] reported 18.20 per cent of incidence of endometritis in in Frieswal crossbred cows in Hyderabad. Postpartum bacterial endometritis is the most common cause of infertility in cows as it delays uterine involution, prolongs the time until first estrus, increases the number of services per conception, and thus prolongs the interval to calving [12]. Bacterial isolation has been reported from uterine secretions of cows suffering from endometritis [13]. A wide variety of bacteria has been recovered from uteri of postpartum cows. Most prevalent pathogens involved in the etiology of endometritis are Arcanobacterium pyogenes, Escherichia coli, Fusobacterium necrophorum and Prevotella species [14,15]. Besides Actinomyces pvogenes, Gram-negative anaerobic bacteria like Fusobacterium necrophorum and Bacteroides spp may have an important role in the pathogenesis of endometritis [11]. Frazier et. al. [16] reported endometritis in postparturient cattle associated with bovine herpesvirus-4 infection. The infections of uterus caused by bacteria are treated with antibiotics. However, the efficacy of such therapeutic agents needs to be evaluated from time to time due to continuous emergence of drug resistant bacterial strains.

Objectives of this study were, to find out the organisms causing endometritis in cattle and to determine their in vitro sensitivity to various antibiotics.

\section{Materials and Methods}

Thirty uterine secretion samples, 9 from Holstein Friesian and 21 from Jersey cows were collected in and around Namakkal district of Tamil Nadu from clinical cases of endometritis. Immediately after collection, sterile nutrient broth was added to each sample and incubated at $37^{\circ} \mathrm{C}$ for over night. These samples were inoculated by streaking method on blood agar, Mac Conkey agar and Nutrient agar. The inoculated media were incubated, both under aerobic and anaerobic conditions, at $37{ }^{\circ} \mathrm{C}$ and examined after every 12 hours till 48 hours post inoculation for the presence of any 
Table-1. Bacteriology of endometritis and in vitro antibiotic sensitivity of the isolates in Holstein Friesian and J ersey cows

\begin{tabular}{|c|c|c|c|c|c|c|c|c|c|}
\hline \multirow[t]{2}{*}{ Name of Organism } & \multirow[t]{2}{*}{ No.of isolates } & \multicolumn{5}{|c|}{ No.of isolates sensitive to } & \multirow[b]{2}{*}{$\mathrm{T}$} & \multirow[b]{2}{*}{$\mathrm{Cf}$} & \multirow[b]{2}{*}{$\mathrm{C}$} \\
\hline & & $\mathrm{Cl}$ & $\mathrm{G}$ & Ex & $\mathrm{Ct}$ & $\mathrm{Am}$ & & & \\
\hline E.coli & 11 & 6 & 5 & 5 & 2 & 3 & 4 & 4 & 2 \\
\hline Klebsiella spp & 9 & 6 & 3 & 2 & 4 & 3 & 3 & 2 & - \\
\hline Proteus spp & 4 & 3 & - & 1 & 1 & - & - & - & - \\
\hline Pseudomonas aeruginosa & 2 & 1 & - & - & 1 & - & - & - & - \\
\hline Clostridium spp & 1 & - & - & - & - & 1 & - & - & - \\
\hline Total & 25 & 16 & 8 & 8 & 8 & 7 & 7 & 6 & 2 \\
\hline Sensitivity (\%) & & 64 & 32 & 32 & 32 & 28 & 28 & 24 & 8 \\
\hline
\end{tabular}

Cl-Ceftriaxone, G-Gentamicin, Ex- Enrofloxacin, Ct- Chlortetracycline, Am- Amoxycilin, T- Tetracycline, Cf- Ciprofloxacin, C- Chloramphenicol

growth. Growth characteristics of the isolates were recorded. The cultures were purified by subculturing and were refrigerated for further studies. The bacteria isolated both aerobically and anaerobically from endometritis showed the characteristic colony, were gram stained and confirmed by standard biochemical tests such as catalase test, oxidase test, indole test, methyl-red test, voges-proskauer test, citrate utilization test and sugar fermentation tests as described by Barrow and Feltham [17]. Each isolate was characterized on the basis of staining behaviour, size, motility and cultural and biochemical tests. All the isolates were tested for in vitro antibiotic sensitivity as per Muneer et. al. [18] as follows. All the isolated colonies were suspended in nutrient broth and then incubated for overnight. The sterile cotton swab was dipped in the bacterial suspension and then rolled over the surface of the Muller-Hinton agar medium and covered evenly with the bacterial suspension. Eight different antibiotic discs were placed over the surface of the agar plate. For this purpose, separate antibiotic discs (Himdedia, Mumbai) containing Gentamicin $10 \mathrm{mg}$, Chloramphenicol $30 \mathrm{mg}$, Enrofloxacin $5 \mathrm{mg}$, Ceftriaxone 30 $\mathrm{mg}$, Amoxycilin $30 \mathrm{mg}$, Tetracycline $30 \mathrm{mg}$, Chlortetracycline $30 \mathrm{mg}$ and Ciprofloxacin $5 \mathrm{mg}$ per discs were employed.

\section{Results}

Various species of bacteria isolated from uterine secretion samples of Holstein Friesian and Jersey cows and their in vitro antibiotic sensitivity to different antibiotics are presented in Table-1. Of the total 30 uterine samples, 25 contained different bacterial strains while 5 were found bacteriologically sterile. Bacterial species isolated from these samples were, Escherichia coli (36.66\%), Klebsiella spp(30\%), Proteus spp (13.33\%), Pseudomonas aeruginosa (6.66\%) and Clostridium spp (3.33\%). In the present study, $16.66 \%$ samples did not show any microbial growth. Since these samples were taken from animals showing clinical signs of endometritis, they cannot be bacteria-free. It is possible that the media/conditions used in the study were not favourable for the growth of micro-organisms present in these samples.

\section{Discussion}

The present study revealed the bacteria E.coli followed by Klebsiella spp are found to be responsible for endometritis in cows. Bhat and Bhattacharyya [19] isolated Staphylococcus spp, E. coli, Bacillus spp, Corynebacterium spp, Pseudomonas spp, Proteus spp, Klebsiella spp and Streptococcus spp from metritis affected crossbred cows of Kashmir valley. Similarly, Costa et. al. [20] isolated Escherichia coli, Pseudomonas aeruginosa, Klebsiella spp, Proteus spp, in more number from uterine discharge and washings of cows suffering from metritis. Shweta [21] also reported the isolation of these organisms from uterine discharge and washings of cows suffering from endometritis. But, Bonnett et. al. [22] reported that endometrial biopsies in Holstein Friesian cows were highly positive for Actinomyces pyogenes followed by Escherichia coli and Streptococci bacteria.The results of in vitro antibiotic sensitivity test in the present study indicated that the maximum number of isolates were sensitive to Ceftriaxone, followed by Gentamicin, Enrofloxacin and Chlortetracycline. Chloramphenicol showed the lowest results in terms of invitro antibiotic sensitivity. However, Muneer et. al. [18] and Bhat and Bhattacharyya [19] reported oxytetracycline to be the best antibiotic for the treatment of metritis in cows. From these results it appears that Ceftriaxone, as well as, Gentamicin, Enrofloxacin, Chlortetracycline are equally effective in treating endometritis in cows.

The use of proper antibiogram is required as a necessity, in the context of variation factors concerning the frequency of different involved bacterial species, and their susceptibility to different antimicrobial products. Although non concordances were found between in vitro and in vivo susceptibility, caused by in vitro instability of germs, different requirements to the culture environment, drug over-dosing or technique errors, the antibiogram could be useful to the practitioner in choosing the most efficient antibacterial products. However, therapeutic trials using these antibiotics should have been carried out to find out the most effective drug.

\section{Conclusion}

This study revealed that the endometritis in cattle is mainly caused by E.coli and Klebisella spp and the drug Ceftriaxone is highly effective.

\section{Author's contribution}

SU carried out the field study and sample analysis. SM participated in sample analysis, scientific discussion. 
KP participated in sample collection, scientific discussion. JR participated in the design of the study and coordination, scientific discussion, drafted and revised the manuscript. All authors read and approved the final manuscript.

\section{Acknowledgements}

The authors acknowledge the Professor and Head of the Department of Clinics, Veterinary College and Research Institute for allowing the collection of samples.

\section{Competing interests}

Authors declare that they have no conflict of interest.

\section{References}

1. Bartlett, P.C., J.H. Kirk, M.A. Wilke, J.B. Kaneene, E.C. Mather. (1986). Metritis complex in Michigan Holstein Frisiancattle: incidence, description, epidemiology and estimated economic impact. Prev. Vet. Med.4: 235-248.

2. Lewis, G.S. (1997). Health problems of the postpartum cow, uterine health and disorders. J. Dairy Sci. 80: 984-994.

3. Bonnett, B.N., S.W. Martin, A.H. Meek.(1993). Associations of clinical findings, bacteriological and histological results of endometrial biopsy with reproductive performance of postpartum dairy cows. Prev. Vet. Med. 15: 205-220.

4. Bondurant, R.H. (1999). Inflammation in the bovine female reproductive tract. J. Anim. Sci.77:101-110.

5. Kaufmann, T.B., M. Drillich, B.A. Tenhagen, D. Forderung and W. Heuwieser. (2009). Prevalence of bovine subclinical endometritis $4 \mathrm{~h}$ after insemination and its effects on first service conception rate. Theriogenology, 71(2): 385-391.

6. Akhtar, M. S., A. A. Farooq and S. Inayat. (2009). Treatment of first degree endometritis by cloprostenol and estradiol in choolistani cows. The Journal of Animal \& Plant Sciences, 19(1): 20-21.

7. Kaufmann,T. B., S. Westermann, M. Drillich, J. Plöntzke and W. Heuwieser. (2010). Systemic antibiotic treatment of clinical endometritis in dairy cows with ceftiofur or two doses of cloprostenol in a 14 day interval. Anim Reprod Sci, $121(1-2): 55-62$.

8. Aeberhard, K., Bruckmaier, R and Blum, J. (1997). High producing cows in Switzerland. Agrarforschung, 4: 277-280.

9. Westermann, S., M. Drillich, T.B. Kaufmann, L.V. Madoz amd W. Heuwieser. (2010). A clinical approach to determine false positive findings of clinical endometritis by vaginoscopy by the use of uterine bacteriology and cytology in dairy cows. Theriogenology,74 (7) :1248-1255.

10. Saini, P. S., A. S.Grewal, A. S. Nanda and A. K. Arora.
(1995). Intra-uterine immunotherapy with immunomodulator lipopolysaccharide (LPS) for bacterial endome $\neg$ tritis associated clinical cases of repeat breeders in dairy cattle (Bos taurus $x$ Bos indicus) and buffaloes (Bubalis bubalis). Bull Soc Fr-Jpn Sci Vet., 6 (2) : 128-134.

11. Muneer, S., K. Sadasiva Rao and K.G. Solmon Raju. (2010). Incidence of reproductive disorders in Frieswal crossbred cows. Indian J. Anim. Res., 44 (3) : 226-227.

12. Griffin, J.F.T., Hartigan, P.J. and Nunn, W.R. (1974). Nonspecific uterine infection and bovine fertility. Theriogenology. 1:91-114.

13. Cohen, R.C., Ziv. G.,. Glickman. A, Winkler. M., Saran A.., Bernstein M., Colodner R. and Kenes J., (1997). Sensitivity to antibiotics of bacteria isolated from uterine secretions of dairy cows with retained fetal membranes and postparturient metritis and concentrations of tetracyclines in uterine secretions after intrauterine administration. Israel $J$. Vet.Med.52: 1

14. Foldi, J., M .Kulcsar, A .Pecsi, B. Huyghe, J.A. Lohuisand, G. Huszenicza. (2006). Bacterial complications of postpartum uterin0e involution in cattle. Anim Reprod Sci, 96:265-281.

15. Sheldon, I.M., J. Cronin, L. Goetze, G. Donofrio and H.J.Schuberth. (2009). Defining postpartum uterine disease and the mechanisms of infection and immunity in the female reproductive tract in cattle. Biology of Reproduction 81(6): 1025-1032.

16. Frazier, K. , Mel Pence, M. J. Mauel, A Liggett, M. E. Hines, L. Sangster, H. D. Lehmkuhl, D. Miller, E. Styer, J. West, C. A. Baldwin. (2001). Endometritis in postparturient cattle associated with bovine herpesvirus-4 infection. $J$ Vet Diagn Invest.,13:502-508.

17. Barrow, G. I. and Feltham, R. K. A. (1993). Cowan and Steel's manual for the identification of medical bacteria, $3^{\text {rd }}$ Edn, Cambridge University Press, Cambridge.

18. Muneer, M. A., Arshad, M., Ahmad, M., Ahmad, I., Rauf, A and Abbas, S. (1991). Antibiotic sensitivity of bacteria causing metritis in cows. Pakistan Vet. J., 11: 78-81.

19. Bhat, F.A. and H.K. Bhattacharyya.(2012). Management of metritis in crossbred cattle of kashmir using oxytetracycline, cephalexin and Prostaglandin F2 $\alpha$. Indian J. Anim. Res., 46 (2) : $187-189$

20. Costa, G.M., Nivaldo Silva, Albuquerque , F.T. and Pereira U.P. (2010). Puerperal endometritis in cows: an etiological survey in the southern of minas gerais/brazil. Cited in www.kenes.com/buiatrics/cd/pdf.

21. Shweta,S. (2003). M.V.Sc Thesis submitted to College of Veterinary and Animal Sciences, CSK, Himachal Pradesh KrishiVishvavidyalaya, Palampur, India.

22. Bonnett, B.N., Martin, S.W. Gannon, V.P.J. Miller R.B. and Etherington, W.G. (1991). Endometrial biopsy in Holstein dairy cows. Canadian J. Vet. Res. 55: 168- 173. 